\title{
The Effect of The Body Composition to Prognosis in Young Breast Cancer Patients
}

\section{Genç Meme Kanserli Hastalarda Vücut Kompozisyonunun Prognostik Etkileri}

Ismail BEYPINAR, Furkan KAYA, Hacer DEMIR ${ }^{1}$

1 Afyonkarahisar University of Health Sciences, Medical Oncology, Afyon, Turkey

${ }^{2}$ Afyonkarahisar University of Health Sciences, Radiology, Afyon, Turkey

Yazıșma Adresi

Correspondence Address

\section{Ismail BEYPINAR}

Afyonkarahisar University of Health Sciences, Medical

Oncology, Afyon, Turkey

ibeypinar@yahoo.com

Geliş tarihi / Received : A ğu 03, 2020 Kabul tarihi / Accepted : Eyl 30, 2020

Elektronik yayın tarihi : Eyl 01, 2021 Online published

Bu makalede yapilacak atı:

Cite this article as:

Beypinar I, Kaya F, Demir H.

The Effect of The Body

Composition to Prognosis in

Young Breast Cancer Patients

Akd Med J / 2021; 7(3):385-391

Ismail BEYPINAR

ORCID ID: 0000-0002-0853-4096

Furkan KAYA

ORCID ID: 0000-0001-8619-7593

Hacer DEMIR

ORCID ID: 0000-0003-1235-9363

\begin{abstract}
Objective

In cancer patients, the effect of the body composition on prognosis is a new clinical area of interest. In patients with class 2 or 3 obesity (BMI $>35$ ), survival was found to be worse control groups in a pooled analysis. BMI category is not truly representing body composition and hard to use to determine the true muscle and fat quantity. Computed tomography $(\mathrm{CT})$ is a frequent method to determine body composition precisely.
\end{abstract}

\section{Material \& Methods}

Axial CT images, including all abdominal muscles (psoas, erector spinae, quadratus lumborum) external and internal oblique and rectus abdominis) total skeletal muscle area (SMA), was calculated. Besides, axial CT images of the body fat subcutaneous adipose and visceral adipose tissue distribution (VAT, SAT) areas were calculated in $\mathrm{cm} 2$ using threshold values of -30 to -190 for adipose tissue.

\section{Results}

Eighty-four women were included in the study. Most of the patients were normal or over-weighted. Invasive carcinoma NST was the dominant histological subtypes, with $94 \%$ of the study population. The count of the sarcopenic and non-sarcopenic patients was 11 and 68 respectively. Although the median OS cannot be reached at the end of the follow-up period for both groups, the difference between groups statistically insignificant. The median OS was not reached for both groups, the difference between low and high TVAT groups was statistically significant. In multivariate analysis, TVAT was found to be an independent risk factor.

\section{Conclusion}

In this study, we demonstrate sarcopenia may be seen in patients with breast cancer under 40 years old, and it may not have a prognostic effect.

Keyword Prognosis, Sarcopenia, Visceral Adipose Tissue, Young Breast Cancer

$\ddot{O}_{z}$

\section{Giriş}

Kanser hastalarında, vücut kompozisyonunun prognoz üzerindeki etkisi yeni bir klinik ilgi alanıdır. Evre 2 veya 3 obezite olan hastalarda sağ kalım, bir meta-analizde kontrol gruplarına oranla daha kötü olarak bulunmuştur. Vücut kitle indeksi kategorisi, vücut kompozisyonunu tam 
olarak temsil etmez ve gerçek kas ve yağ miktarını belirlemek için kullanımı zordur. Bilgisayarlı tomografi (BT) vücut kompozisyonunu kesin olarak belirlemek için sık kullanılan bir yöntemdir.

\section{Gereç ve Yöntemler}

Tüm karın kasları (psoas, diken omurga, kuadratus lumborum) dış ve iç oblik ve rektus abdominis dahil olmak üzere aksiyal BT görüntüleri toplam iskelet kası alanı (SMA) hesaplandı. Ayrıca, subkütanöz adipoz ve viseral adipoz doku dağılımı (VAT, SAT) alanlarının aksiyal BT görüntüleri, adipoz doku için -30 ila -190 eşik değerleri kullanılarak cm2 cinsinden hesaplanmıştır.

\section{Bulgular}

Seksen dört kadın çalışmaya dahil edildi. Hastaların çoğu normal veya aşırı ağırlıklı idi. İnvaziv karsinom NST, çalışma popülasyonunun \% 94'ünde baskın histolojik alt tiplerdi. Sarkopenik ve sarkopenik olmayan hastaların sayısı sırasıyla 11 ve 68 idi. Her iki gruptaki hastalar için ortalama genel sağkalıma (OS) takip süresinin sonunda ulaşılamasa da, gruplar arasındaki fark istatistiksel olarak anlamsızdı. Her iki grup için ortanca OS'ye ulaşılmadı, düşük ve yüksek VAT grupları arasındaki fark istatistiksel olarak anlamlıydı. Çoklu analizlerde VAT bağımsız bir risk faktörü olarak saptandı.

\section{Sonuç}

$\mathrm{Bu}$ çalışmada sarkopeninin 40 yaşın altındaki meme kanseri hastalarında görülebildiğini ve prognostik bir etkisi olmadığını gösterdik.

Anahatar Kelimeler Genç Meme Kanseri, Prognoz, Sarkopeni, Viseral Yağ Dokusu

The study was approved by the ethics committee at Afyonkarahisar Health Sciences University Faculty of Medicine and carried out by the Declaration of Helsinki principles and all applicable regulations. The decision number and date of the ethics committee were 2020/1-35 and 03.01.2020 respectively.

\section{Introduction}

In cancer patients, the effect of the body composition on prognosis is a new clinical area of interest (1). Obesity is an increasing disease burden worldwide. In the USA, nearly $40 \%$ percent of the adult female population was categorized as obese (2). The difference in body composition between sexes was observed in many studies. In both healthy subjects and cancer patients, males had higher muscularity while females had greater adipose tissue (3-5).

Obesity is considered to be related to both etiology, drug resistance, and decreased survival in breast cancer. In patients with high BMI who treated with neoadjuvant chemotherapy decreased complete responses and survival was observed when compared with the normal population (6-8). Although obesity has metabolic dysregulations and predisposition for many diseases, some obese or over-weight populations remain metabolically normal which is called the 'obesity paradox'(9). In patients with decreased muscle volume which was masked due to an increase in BMI, the 'sarcopenic obesity' term was defined (10). BMI category is not truly representing body composition and hard to use to determine the true muscle and fat quantity (11).

Cachexia is reported to be associated with increased mortality and morbidity in cancer patients (12-14). The protein catabolism which constitutes the main structure of the skeletal muscle emphasized for chronic conditions such as chronic obstructive disease and cancer (15-17).

On the other hand, low BMI may cover the low muscularity and increased adiposity in some patients. For these limitations of the BMI, the studies investigating the effect of body composition on prognosis are increasing in breast cancer (18-23).

One of the features of malnutrition was described as sarcopenia, which was defined by decreased muscle mass and quality (24).

Computed tomography (CT) is a frequent method to determine body composition precisely. Body composition assessment with $\mathrm{CT}$ is a specific method for the calculation of muscle quality and adipose tissue (25).

In this study, we try to evaluate the relationship between the sarcopenia and visceral adiposity with the clinical features and survival in women under 40 with breast cancer.

\section{Patients \& Methods}

\section{Study Participants}

The archive records of patients between 2012 and 2019, diagnosed breast cancer at the Afyonkarahisar Health Sciences University Oncology Department were retrospectively analyzed. The patients who are under forty were included in the study. The patient characteristics, pathologic subtype, estrogen receptor (ER), Human epidermal growth factor receptor-2 (HER-2) status, stage of the disease, treatment modalities, disease recurrence, and last control or death dates were recorded. The exclusion criteria were lack of adequate cancer diagnosis, CT images, and follow-up.

\section{Ethics}

The study was approved by the ethics committee at Afyonkarahisar Health Sciences University Faculty of Medicine and carried out by the Declaration of Helsinki principles and all applicable regulations. The decision number and date of the ethics committee were 2020/1-35 and 03.01.2020 respectively.

\section{Statistical Analyze}

The statistical analysis of the study performed with SPSS software (Statistical Package for

the Social Sciences, version 22.0, SPSS Inc, Chicago, IL). Descriptive data are presented as either means or median for continuous variables, frequencies and percentages are reported for categorical variables. ROC analysis will be performed to determine the optimal cut-off value. Pearson X2 test is used to assessing the associations in categorical variables. OS curves are estimated by the Kaplan-Meier product-limit method. Life tables were established to determine the propor- 
tional survival analysis.

Body Composition Assessment and CT analyze

Axial CT images including all abdominal muscles (psoas, erector spinae, quadratus lumborum) external and internal oblique and rectus abdominis) total skeletal muscle area (SMA) was calculated. The total sarcopenia index (TSI) was calculated by dividing the square of the patient's height by the square meter $(\mathrm{cm} 2 / \mathrm{m} 2)$. Patients with a TSI lower than 38.9 $\mathrm{cm} 2 / \mathrm{m} 2$ for female patients were considered to have decreased skeletal muscle mass. (14) Also, axial CT images of the body fat subcutaneous adipose and visceral adipose tissue distribution (VAT, SAT) areas were calculated in $\mathrm{cm} 2$ using threshold values of -30 to -190 for adipose tissue. The total VAT cut-off value was calculated by ROC analysis and accepted as $134.3 \mathrm{~cm} 2$

\section{Results}

Eighty-four women were included in the study. Four patients' body weight or height data cannot be established. The mean age of the participants was 34.9 years. The mean weight, height, and BMI were $69.45 \mathrm{~kg}, 1,59$ meters, and $27.13 \mathrm{~kg} / \mathrm{m} 2$ respectively. The BMI was categorized according to the cut-off values below 18.5, 18.6-25, and above $25.1 \mathrm{~kg} / \mathrm{m} 2$. The patient distribution due to the BMI cut-off values was 1 , 39 , and 40 respectively. Most of the patients were normal or over-weighted. Invasive carcinoma NST was the dominant histological subtypes with $95 \%$ of the study population. Ninety-five percent of the patients were a non-smoker. The distribution of the patients due to stages 1 to 4 ordinally at the diagnosis was 27, 29,21, and 7 respectively. Eleven disease relapses were observed during follow-up which mostly occurred with bonny metastases. Most of the patients undergoing surgery with the nearly same frequency of both mastectomy (MRM) and breast-conserving surgery (BCS) (MRM/BCS:40/38). (Table-1) The mean values of the total, subcutaneous, intramuscular, and visceral adipose tissue were $381.03 \mathrm{~cm} 2,272.1 \mathrm{~cm} 2,19.4 \mathrm{~cm} 2$, and $87.08 \mathrm{~cm} 2$ respectively. The mean psoas and total muscle area were 16.14 and $113.3 \mathrm{~cm} 2$ respectively.
Table I Features of the patient population.

\begin{tabular}{ll}
\hline Features & Number (\%) \\
\hline BMI & $1(1.25 \%)$ \\
$<18.5 \mathrm{~kg} / \mathrm{m}^{2}$ & $39(38.75 \%)$ \\
\hline $18.6-25 \mathrm{~kg} / \mathrm{m}^{2}$ & $40(50 \%)$ \\
$>25.1 \mathrm{~kg} / \mathrm{m}^{2}$ & \\
\hline Histology & $80(95 \%)$ \\
\hline Invasive Carcinoma NST & $4(5 \%)$ \\
\hline Other & \\
\hline Smoking Status & $4(5 \%)$ \\
\hline Smoker & $80(95 \%)$ \\
\hline Non-Smoker & \\
Stage & $27(33 \%)$ \\
I & $29(34 \%)$ \\
II & $21(25 \%)$ \\
III & $7(8 \%)$ \\
IV & $40(47 \%)$ \\
Surgery Type & $38(45 \%)$ \\
Mastectomy & $6(7 \%)$ \\
BCS & \\
Not operated & $68(80 \%)$ \\
Oestrogen Receptor & $16(20 \%)$ \\
\hline Positive & \\
Negative & $20(24 \%)$ \\
HER-2 & $64(76 \%)$ \\
Positive & \\
Negative & $75(89 \%)$ \\
Adj. Chemotherapy & $9(11 \%)$ \\
Received & \\
Not-Received & $63(76 \%)$ \\
Adj. Radiotherapy & $20(24 \%)$ \\
Received & \\
Not-Received & \\
Adj.: Adjuvant, BCS: Breast-Conserving Surgery, BMI: Body Mass Index, HER-2: \\
Human Epidermal Growth Factor Receptor-2 \\
\hline
\end{tabular}

When patients categorized according to the TSI, the count of the sarcopenic and non-sarcopenic patients was 11 and 68 respectively. Although the median OS cannot be reached at the end of the follow-up period for both sarcopenic and non-sarcopenic patients, the difference between groups statistically insignificant $(\mathrm{p}=0.12)$. The percentage of patients who were still alive 4 th year was $87 \%$ and $97 \%$ favoring the non-sarcopenic group. The clinical factors smoking status, histologic subtype, ER status, HER-2 over-expression, type of the surgery, tumor size, metastatic disease at the diagnosis, and disease recurrence were not significant when the groups compared. Only the nodal status at the time of diagnosis was different between groups $(\mathrm{p}=0.03)$.

When patients were categorized by BMI as normal and over-weight, the median OS was not significantly different, although the follow-up period was not sufficient for both groups. $(p=0.07)$ The percentage of the patients were $\% 92$ and $100 \%$ favoring the normal BMI group. The clinical factors among the over-weight and normal groups were similar. The clinical features according to BMI categories was shown in Table-2. 
Table II The clinical features according to BMI categories.

\begin{tabular}{|c|c|c|c|}
\hline Features & BMI $\leq 25$ & BMI $>25$ & p-value \\
\hline \multicolumn{4}{|l|}{ Histology } \\
\hline \multicolumn{4}{|l|}{ NST } \\
\hline Other & $2(50)$ & $2(50)$ & \\
\hline \multicolumn{4}{|l|}{ Smoking Status } \\
\hline Smoker & $0(0)$ & $4(100)$ & 0,11 \\
\hline Non-Smoker & $31(38,8)$ & $49(61,2)$ & \\
\hline \multicolumn{4}{|l|}{ Stage } \\
\hline I & $11(40,7)$ & $16(59,3)$ & 0,21 \\
\hline II & $12(41,4)$ & $17(58,6)$ & \\
\hline III & $4(19)$ & $17(81)$ & \\
\hline IV & $4(57,1)$ & $3(42,9)$ & \\
\hline \multicolumn{4}{|l|}{ Surgery Type } \\
\hline Mastectomy & $14(35)$ & $26(65)$ & 0,45 \\
\hline $\mathrm{BCS}$ & $16(42,1)$ & $22(57,9)$ & \\
\hline Not operated & $1(16,7)$ & $5(83,3)$ & \\
\hline \multicolumn{4}{|l|}{ Oestrogen Receptor } \\
\hline Positive & $27(30,7)$ & $41(60,3)$ & 0,27 \\
\hline Negative & $4(25)$ & $12(75)$ & \\
\hline \multicolumn{4}{|l|}{ HER-2 } \\
\hline Positive & $6(30)$ & $14(70)$ & 0,46 \\
\hline Negative & $25(39,1)$ & $39(60,9)$ & \\
\hline \multicolumn{4}{|l|}{ Adj. Chemotherapy } \\
\hline Received & $28(37,3)$ & $47(62,7)$ & 0,81 \\
\hline Not-Received & $3(33,3)$ & $6(66,7)$ & \\
\hline \multicolumn{4}{|l|}{ Adj. Radiotherapy } \\
\hline Received & $24(38,1)$ & $39(61,9)$ & 0,51 \\
\hline Not-Received & $6(30)$ & $14(70)$ & \\
\hline BSC: Breast-Consery & g Surgery & & \\
\hline
\end{tabular}

Although the median OS was not reached for both groups, the difference between low and high TVAT groups was statistically significant. $(\mathrm{p}=0.047)$ (Figure-1) The four, five- and six-years survival percentage of patients were $97 \%$ for the low TVAT group while the high VAT group had $87 \%, 78 \%$, and $64 \%$, respectively. The clinical factors were similar between groups except for the type of surgery, which favored BCS among the low TVAT group. The TVAT remained to be an independent risk factor for OS with a borderline significance in multivariate analysis. $(p=0.059)$ The OS difference between groups was disappeared when de novo metastatic patients excluded. $(\mathrm{p}=0.14)$

Figure I The Kaplan-Meier curve of the TVAT group.

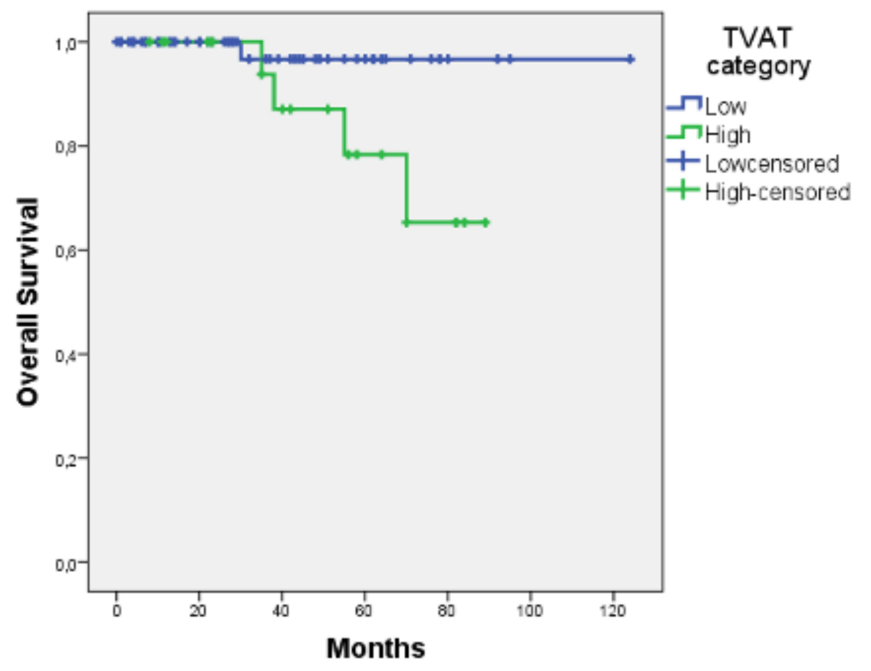

\section{Discussion}

In our study, TVAT was confirmed to be a prognostic risk factor that reached statistical significance. Although the median OS was not reached in non-sarcopenic and sarcopenic patients, the non-sarcopenic patients had a trend to better OS. BMI status of the patients was not different in terms of OS, although a non-significant trend was favoring normal weighed patients. In patients younger than 40 years, TVAT may be a better prognostic factor than TSI due to healthy muscle structure.

In chronic conditions, decreased muscle volume was shown to be related to poor prognosis rather than obesity and fat, especially in metabolic diseases. The role of the potential role of the muscle catabolism in disease physiopathology is still under investigation $(26,27)$. Sarcopenia is a frequent phenomenon in cancer patients which is also related to poor survival (28-31).

The frequently studied parameter in breast cancer patients is body mass index (BMI), which is calculated as weight in kilograms divided by height in squared meters. In patients with class 2 or 3 obesity $(\mathrm{BMI}>35)$ survival was found to be worse control groups in a pooled analysis. The lower levels of obesity had conflicting results in several studies (32-34).

The literature was evaluating sarcopenia and TVAT in breast cancer mainly composed of metastatic and adjuvant studies. Although multiple studies designed to evaluate the prognostic value of body composition in breast cancer, to our knowledge, our study is the first for young breast cancer patients.

Bette et al. reported sarcopenia was a better prognostic indicator than visceral adiposity. Low muscle volume is related to decreased survival and considered to be a better marker than BMI. Although this trial had the largest patient number, the age factor cut-off was determined as 55 years, which was inaccurate for young breast cancer. Also, the proportion of young breast cancers was not specified (35). Even though our study had a better cut-off value to determine young age for breast cancer patients, the optimal age is still unknown for age-related alteration for body composition. Stage, as well as age, maybe another cornerstone to evaluate the body composition which may be affected by disease burden.

Five studies only reported the prognostic effect of sarcopenia in breast cancer. Three studies were designed in a metastatic patient group while two studies were composed of non-metastatic patients $(18,20-23)$. Only one of these studies demonstrated an increased risk of death in sarcopenic patients (22). In another study, which reported sarcopenia to have a relation with over-all mortality in non-metastatic breast cancer patients, had a small number of events and evaluated TSI after chemotherapy (23). Also, the composition of the muscle reported being an important factor in over-all mortality. Rier et al. found low muscle radiodensity was associated with increased overall mortality in the metastatic state (21). This finding was speculated to be related to inflammatory conditions, and the immune system was supported by more trials (36-38).

One previous study reported a relationship between mortality and muscle density in metastatic patients in terms of very low 
mean cut-off value when compared with non-metastatic patients $(21,35)$. The difference was hypothesized for the accumulation of fat tissue among muscles with the increased stage and disease burden, which also explained the difference in the cut-off value of muscle density in these populations.

Our study had compatible results with earlier studies in terms of visceral adiposity. Three previous studies reported decreased distant disease-free and overall survival in locally advanced breast cancer in patients with high visceral adiposity $(18,19,35)$. Even TVAT was found to be an independent risk factor in our study for young breast cancer patients, it may be more important in the de-novo metastatic population. The increased tumor burden might be effective in the alteration of body composition. Additional studies, specific to the de novo metastatic population may answer the question.

Although other studies had young patient populations, our study specifically designed to investigate the body composition of young breast cancer to avoid the change in time via life-style changes and co-morbidities. The effect of muscle tissue on prognosis may be lesser important than adipose tissue in young breast cancers.

\section{Limitations}

The cross-sectional design of the study had limitations to evaluate patient characteristics. All CT or PET-CT images were gathered at the time of diagnosis, which may have a difference between de-novo metastatic and recurrent patients. Also, the small patient population does not allow subgroup analysis for recurrent or de-novo metastatic groups. Small numbers of recurrences do not allow disease-free survival analysis. The effect of lifestyle interventions, tolerance of adjuvant treatment, and toxicity profiles cannot be evaluated due to the retrospective design of the study.

\section{Conclusion}

In this study, we demonstrate sarcopenia may be seen in patients with breast cancer under 40 years old, and it may not have a prognostic effect. The visceral abdominal fat tissue may have a greater effect on survival in breast cancer in the early period of life span. Although both muscle and fat tissue can be modifiable risk factors for breast cancer, more prospective studies observing the effect of body composition before and during breast cancer may determine the role of these parameters more accurately.

\section{Disclosure}

The authors have stated that they have no conflict of interest. The study received no funding from commercial or non-commercial organizations.

The study was approved by the ethics committee at Afyonkarahisar Health Sciences University Faculty of Medicine and carried out by the Declaration of Helsinki principles and all applicable regulations. The decision number and date of the ethics committee were 2020/1-35 and 03.01.2020 respectively.
IB: Designing the study, working with statistics, and writing the article

FK: Collecting data

HD: Reviewing the article, mentor.

\section{References}

1. A. Ligibel, D. Wollins, American society of clinical oncology obesity initiative: Rationale, progress, and future directions. J. Clin. Oncol. 2016; 34:4256-4260.

2. C.M. Hales, M.D. Carroll, C.D. Fryar, C.L. Ogden, Prevalence of Obesity Among Adults and Youth: United States, 2015-2016. NCHS Data Brief. 2017; 288:1-8

3. E. Blaak, Gender differences in fat metabolism. Curr. Opin. Clin. Nutr. Metab. Care. 2001; 4:499-502.

4. E.B. Geer, W. Shen, Gender differences in insulin resistance, body composition, and energy balance. Gend. Med. 2009; 6:60-75.

5. M. Ebadi, L. Martin, S. Ghosh, C.J. Field, R. Lehner, V.E. Baracos, V.C. Mazurak, Subcutaneous adiposity is an independent predictor of mortality in cancer patients. Br. J. Cancer. 2017; 117:148-155.

6. C. Fontanella, B. Lederer, S. Gade, M. Vanoppen, J.U. Blohmer, S.D. Costa, C. Denkert, H. Eidtmann, B. Gerber, C. Hanusch, J. Hilfrich, J. Huober, A. Schnee weiss, S. Paepke, C. Jackisch, K. Mehta, V. Nekljudova, M. Untch, P. Neven, G. von Minckwitz, S. Loibl, Impact of body mass index on neoadjuvant treatment outcome: a pooled analysis of eight prospective neoadjuvant breast cancer trials. Breast Cancer Res. Treat. 2015; 150:127-139.

7. T. Iwase, R. Nakamura, N. Yamamoto, A. Yoshi, M. Itami, M. Miyazaki, The effect of molecular subtype and body mass index on neo-adjuvant chemotherapy in breast cancer patients, Breast. 2014; 23:264-272.

8. J.K. Litton, A.M. Gonzalez-Angulo, C.L. Warneke, A.U. Buzdar, S.W. Kau, M. Bondy, S. Mahabir, G.N. Horto bagyi, A.M. Brewster, Relationship between obesity and pathologic response to neoadjuvant chemotherapy among women with operable breast cancer. J. Clin. Oncol. 2008; 26:4072-4077

9. G. V. Denis, M.S. Obin, "Metabolically healthy obesity": Origins and implications. Mol. Aspects Med. 2013; 34:59-70.

10. C.M. Prado, J.R. Lieffers, L.J. McCargar, T. Reiman, M.B. Sawyer, L. Martin, V.E. Baracos, Prevalence and clinical implications of sarcopenic obesity in patients with solid tumours of the respiratory and gastrointestinal tracts: a population-based study. Lancet Oncol. 2008; 9:629-635.

11 . N. Noori, C.P. Kovesdy, R. Dukkipati, Y. Kim, U. Duong, R. Bross, A. Oreopoulos, A. Luna, D. Benner, J.D. Kopple, K. Kalantar-Zadeh, Survival predictability of lean and fat mass in men and women undergoing mainte nance hemodialysis. Am. J. Clin. Nutr. 2010; 
92:1060-1070.

12 . N. Johns, N.A. Stephens, K.C.H. Fearon, Muscle wasting in cancer. Int. J. Biochem. Cell Biol. 2013; 45:2215-2229.

13 . K.C.H. Fearon, D.J. Glass, D.C. Guttridge, Cancer cachexia: Mediators, signaling, and metabolic pathways. Cell Metab. 2012; 16;153-166.

14 . K. Fearon, F. Strasser, S.D. Anker, I. Bosaeus, E. Bruera, R.L. Fainsinger, A. Jatoi, C. Loprinzi, N. MacDonald, G. Mantovani, M. Davis, M. Muscaritoli, F. Ottery, L. Radbruch, P. Ravasco, D. Walsh, A. Wilcock, S. Kaasa, V.E. Baracos, Definition and classification of cancer cachexia: An international consensus. Lancet Oncol. 2011; 12:489-495.

15 . C. van de Bool, H.R. Gosker, B. van den Borst, C.M. Op den Kamp, I.G.M. Slot, A.M.W.J. Schols, Muscle Quali ty is More Impaired in Sarcopenic Patients With Chronic Obstructive Pulmonary Disease. J. Am. Med. Dir. Assoc. 2016; 17:415-420.

16. A.S. Ryan, F.M. Ivey, S. Prior, G. Li, C. Hafer-Macko, Skeletal muscle hypertrophy and muscle myostatin reduction after resistive training in stroke survivors. Stroke 2011; 42:416-420

17. V. Baracos, S.M.R. Kazemi-Bajestani, Clinical outcomes related to muscle mass in humans with cancer and catabolic illnesses. Int. J. Biochem. Cell Biol. 2013; $<45: 2302-2308$.

18. E. Del Fabbro, H. Parsons, C.L. Warneke, K. Pulivarthi, J.K. Litton, R. Dev, S.L. Palla, A. Brewster, E. Bruera, The Relationship Between Body Composition and Response to Neoadjuvant Chemotherapy in Women with Operable Breast Cancer. Oncologist. 2012; 17:1240-1245.

19. T. Iwase, T. Sangai, T. Nagashima, M. Sakakibara, J. Sakakibara, S. Hayama, E. Ishigami, T. Masuda, M. Miyazaki, Impact of body fat distribution on neoadjuvant chemotherapy outcomes in advanced breast cancer patients. Cancer Med. 2016; 5:41-48.

20 . C.M.M. Prado, V.E. Baracos, L.J. McCargar, T. Reiman, M. Mourtzakis, K. Tonkin, J.R. Mackey, S. Koski, E. Pituskin, M.B. Sawyer, Sarcopenia as a determinant of chemotherapy toxicity and time to tumor progression in metastatic breast cancer patients receiving capecitabine treatment. Clin. Cancer Res. 2009; 15:2920-2926.

21 . H.N. Rier, A. Jager, S. Sleijfer, J. van Rosmalen, M.C.J.M. Kock, M.D. Levin, Low muscle attenuation is a prognostic factor for survival in metastatic breast cancer patients treated with first line palliative chemo therapy. Breast 2017; 31:9-15.

22 . S.S. Shachar, A.M. Deal, M. Weinberg, K.A. Nyrop, G.R. Williams, T.F. Nishijima, J.M. Benbow, H.B. Muss, Skeletal muscle measures as predictors of toxicity, hospi talization, and survival in patients with metastatic breast cancer receiving taxane-based chemotherapy. Clin. Cancer Res. 2017; 23:658-665.

23 . A. Villaseñor, R. Ballard-Barbash, K. Baumgartner, R. Baumgartner, L. Bernstein, A. McTiernan, M.L.
Neuhouser, Prevalence and prognostic effect of sarcope nia in breast cancer survivors: The HEAL Study. J. Cancer Surviv. 2012; 6:398-406.

24 . J. V. White, P. Guenter, G. Jensen, A. Malone, M. Schof ield, Consensus statement: Academy of nutrition and dietetics and American society for parenteral and enteral nutrition: Characteristics recommended for the identifi cation and documentation of adult malnutrition undernu trition .. J. Parenter. Enter. Nutr. 2012; 36:275-283.

25 . W. Shen, M. Punyanitya, Z.M. Wang, D. Gallagher, M.P. St.-Onge, J. Albu, S.B. Heymsfield, S. Heshka, Total body skeletal muscle and adipose tissue volumes: Estimation from a single abdominal cross-sectional image. J. Appl. Physiol. 2004; 97:2333-2338

26 . A.M.J. Sanchez, A. Csibi, A. Raibon, A. Docquier, J. Lagirand-Cantaloube, M.-P. Leibovitch, S.A. Leibovitch, H. Bernardi, eIF3f: a central regulator of the antagonism atrophy/hypertrophy in skeletal muscle. Int. J. Biochem. Cell Biol. 2013; 45:2158-2162.

27 . S.H. Lecker, R.T. Jagoe, A. Gilbert, M. Gomes, V. Baracos, J. Bailey, S.R. Price, W.E. Mitch, A.L. Gold berg, Multiple types of skeletal muscle atrophy involve a common program of changes in gene expression. FASEB J. 2004; 18:39-51.

28 . M. Pressoir, S. Desné, D. Berchery, G. Rossignol, B. Poiree, M. Meslier, S. Traversier, M. Vittot, M. Simon, J.P. Gekiere, J. Meuric, F. Serot, M.N. Falewee, I. Rodrigues, P. Senesse, M.P. Vasson, F. Chelle, B. Maget, S. Antoun, P. Bachmann, Prevalence, risk factors and clinical implications of malnutrition in french compre hensive cancer centres, Br. J. Cancer. 2010; 102:966-971.

29. D. Nishikawa, N. Hanai, H. Suzuki, Y. Koide, S. Beppu, Y. Hasegawa, The Impact of Skeletal Muscle Depletion on Head and Neck Squamous Cell Carcinoma. ORL. 2018; 80:1-9.

30 . L. Martin, L. Birdsell, N. MacDonald, T. Reiman, M.T. Clandinin, L.J. McCargar, R. Murphy, S. Ghosh, M.B. Sawyer, V.E. Baracos, Cancer cachexia in the age of obesity: Skeletal muscle depletion is a powerful prognos tic factor, independent of body mass index. J. Clin. Oncol. 2013; 31:1539-1547

31. S. O'Brien, M. Twomey, F. Moloney, R.G. Kavanagh, B.W. Carey, D. Power, M.M. Maher, O.J. O’Connor, C. Ó'Súilleabháin, Sarcopenia and post-operative morbidity and mortality in patients with gastric cancer. J. Gastric Cancer 2018; 18:242-252.

32 . M.L. Kwan, W.Y. Chen, C.H. Kroenke, E.K. Weltzien, J.M. Beasley, S.J. Nechuta, E.M. Poole, W. Lu, M.D. Holmes, C.P. Quesenberry, J.P. Pierce, X.O. Shu, B.J. Caan, Pre-diagnosis body mass index and survival after breast cancer in the after Breast Cancer Pooling Project. Breast Cancer Res. Treat. 2012; 132:729-739.

33. D.S.M. Chan, A.R. Vieira, D. Aune, E. V. Bandera, D.C. Greenwood, A. McTiernan, D. Navarro Rosenblatt, I. Thune, R. Vieira, T. Norat, Body mass index and survival in women with breast cancer-systematic literature review and meta-analysis of 82 follow-up studies. Ann. Oncol. 
2014; 25:1901-1914.

34 . H. Greenlee, J.M. Unger, M. LeBlanc, S. Ramsey, D.L. Hershman, Association between body mass index and cancer survival in a pooled analysis of 22 clinical trials, in: Cancer Epidemiol. Biomarkers Prev., 2017; 19:310-322.

35 . B.J. Caan, E.M. Cespedes Feliciano, C.M. Prado, S. Alexeeff, C.H. Kroenke, P. Bradshaw, C.P. Quesenberry, E.K. Weltzien, A.L. Castillo, T.A. Olobatuyi, W.Y. Chen, Association of muscle and adiposity measured by computed tomography with survival in patients with nonmetastatic breast cancer. JAMA Oncol. 2018; 4:798-804.

36 . E.M.C. Feliciano, C.H. Kroenke, J.A. Meyerhardt, C.M. Prado, P.T. Bradshaw, M.L. Kwan, J. Xiao, S. Alexeeff, D. Corley, E. Weltzien, A.L. Castillo, B.J. Caan, Associa tion of Systemic Inflammation and Sarcopenia With Survival in Nonmetastatic Colorectal Cancer: Results From the C SCANS Study. JAMA Oncol. 2017; 3:72319.

37 . G. Malietzis, G.H. Lee, D. Bernardo, A.I.F. Blakemore, S.C. Knight, M. Moorghen, H.O. Al-Hassi, J.T. Jenkins, The prognostic significance and relationship with body composition of CCR7-positive cells in colorectal cancer. J. Surg. Oncol. 2015; 112:86-92.

38 . G. Malietzis, N. Johns, H.O. Al-Hassi, S.C. Knight, R.H. Kennedy, K.C.H. Fearon, O. Aziz, J.T. Jenkins, Low muscularity and myosteatosis is related to the host systemic inflammator y response in patients undergoing surger y for colorectal cancer. Ann. Surg. 2016; 263:320-325. 